\title{
Radiorespirometric Analysis of Glucose Metabolism in the Rat during Feeding with $3^{\prime}$-Methyl-4-(dimethylamino) azobenzene
}

\author{
-Radiorespirometry using $\left[1-{ }^{14} \mathrm{C}\right]$ glucose -
}

\author{
Shyuji KoJIMA, Nagatoshi IsHII*, Yasuko SHIKI* and Akiko KUBODERA* \\ Faculty of Pharmaceutical Sciences, Teikyo University, Suarashi 1091-1, Sagamiko-machi, \\ Tukui-gun, Kanagawa 199-01, *Faculty of Pharmaceutical Sciences, Science University \\ of Tokyo, Funagawara-cho 12, Ichigaya, Shinjuku-ku, Tokyo 162
}

Received April 4, 1979

We estimated the enzyme activities on the hexose monophosphate oxidative pathway of glucose metabolism at an early stage during feeding with $3^{\prime}$-methyl-4-(dimethylamino) azobenzene $\left(3^{\prime}-M e-D A B\right)$ in the first paper of this series. In the present paper, the importance of this non-glycolytic pathway of glucose metabolism in preneoplastic liver in azodye fed rat was studied by radiorespirometry using $\left[1-{ }^{14} \mathrm{C}\right]$ glucose and $\left[6-{ }^{14} \mathrm{C}\right]$ glucoce. In addition to radioisotope analysis, the level of activity of glucose-6-phosphate dehydrogenase was measured in rat liver after various periods of feeding with $3^{\prime}-M e-D A B$.

In radiorespirometry using $\left[1^{-14} \mathrm{C}\right]$ glucose, the peak time was delayed up to the 2 nd week, but was early by the 4th week and was the same as the control at the 5th week and thereafter. On the other hand, the peak height and the yield value both changed in almost the same way. That is to say, they were lower than those of the control until the 2nd week, began to increase from the $3 r d$ week, reached a maximum at the 4th week, and remained at the control level at the 5th week and thereafter. Moreover, the yield value ratio of respiratory ${ }^{14} \mathrm{CO}_{2}$ from $\left[1^{14} \mathrm{C}\right]$ glucose to that from $\left[6-{ }^{-14} \mathrm{C}\right]$ glucose increased from 1.3 to 1.52 at the $3 r d$ to 4 th week after feeding with $3^{\prime}-M e-D A B$.

The activity of glucose-6-phosphate dehydrogenase increased as early as the 2nd week after the start of feeding with $3^{\prime}-M e-D A B$, reaching a maximum at the 4 th reeek. Thereafter, the activity remained high with a slight decrease from the maximum by the 6th week.

The incorporations of $\left[{ }^{3} \mathrm{H}\right]$ thymidine and $\left[U-{ }^{14} \mathrm{C}\right]$ glucose into rat liver DNA at the 4th week after feeding with $3^{\prime}-M e-D A B$ were both as high as 2 to 4 times those of the control.

Key Words: $3^{\prime}$-methyl-4-(dimethylamino) azobenzene, $\left[1^{-14} \mathrm{C}\right]$ glucose, $\left[6^{-14} \mathrm{C}\right]$ glucose, hexose monophosphate oxidative pathway, radiorespirometry

\section{Introduction}

In our previous paper $^{1)}$, we suggested that the hexose monophosphate (HMP) oxidative pathway was activated at an early stage during feeding with $3^{\prime}$-methyl-4-(dimethylamino) azobenzene (3'-Me-DAB), on the basis of the changes in radiorespirometry and glycolytic enzyme activity.

It is well known that the HMP pathway is active in cases of tumors ${ }^{2-12)}$, liver injury ${ }^{13)}$, regenerating liver ${ }^{14)}$, embryos, and hyperthyroid- ism $^{15-16)}$, of experimental animals. Since one of the main functions of this pathway is to supply ribose-5-phosphate for incorporation into nucleic acids and coenzymes, it is expected to play an important role in glucose metabolism in tumors and other actively dividing cells.

Watabe ${ }^{17)}$ reported that a transient appearance of serum $\alpha$-fetoprotein at an early stage of azodye carcinogenesis in the rat largely coincided with the time of rapid oval cell proliferation. Thus, our previous report ${ }^{11}$ could be related to oval cell proliferation at an early stage during 
feeding with $3^{\prime}$-Me-DAB.

In this paper, radiorespirometry using $\left[1-{ }^{-14} \mathrm{C}\right]$ glucose and $\left[6-{ }^{14} \mathrm{C}\right]$ glucose was carried out in order to confirm the activation of the HMP pathway at an early stage during feeding with $3^{\prime}$-Me-DAB, and the activity of glucose-6-phosphate dehydrogenase (D-glucose-6-phosphate: $\mathrm{NADP}^{+}$oxidoreductase, EC 1.1.1.49), was also determined.

\section{Materials and Methods}

Male rats of the Donryu strain (Nihon Rat Co., Urawa), weighing about $180 \mathrm{~g}$ were fed on a synthetic diet containing $0.06 \%$ of $3^{\prime}$-Me-DAB (Oriental Yeast Co. Ltd., Tokyo, Japan) for 6 weeks. The control rats were fed on the basal diet, CE-2 (Clea Japan Inc., Tokyo), throughout the experiments.

\section{$2 \cdot 1$ Radiorespirometry}

The radiorespirometric patterns were obtained by the method ${ }^{11}$ described previously, using $\left[1^{-14} \mathrm{C}\right]$ glucose and $\left[6-{ }^{-14} \mathrm{C}\right]$ glucose as substrates. The labelled glucose substrates were purchased from New England Nuclear Co., USA. The specific activity of $\left[1^{-14} \mathrm{C}\right]$ glucose was $57 \mathrm{mCi} /$ mmole, and that of $\left[6-{ }^{-14} \mathrm{C}\right]$ glucose was $53 \mathrm{mCi} /$ mmole. In each experiment, $2.5 \mu \mathrm{Ci}$ of a labelled glucose was injected intraperitoneally every week for 6 weeks during feeding with $3^{\prime}$-MeDAB.

\subsection{Assays of pyruvate kinase and glucose-} 6-phosphate dehydrogenase

Activity of pyruvate kinase (PK) was measured as described previously ${ }^{1}$. Glucose-6-phosphate dehydrogenase (G-6-PD) was determined spectrophotometrically at $37^{\circ}$ by the rate of NADPH formation at $340 \mathrm{~nm}$ with a Gilford recording spectrophotometer 250 . The reaction mixture consisted of $2.0 \mathrm{~m} l$ of $0.25 \mathrm{M}$ glycylglycine (pH 7.6), $0.5 \mathrm{~m} l$ of $0.1 M \mathrm{MgCl}_{2}, 0.05 \mathrm{ml}$ of liver supernatant and $0.05 \mathrm{~m} l$ of NADP $(10 \mathrm{mg}$ / $\mathrm{m} l$ ). The reaction was started by the addition of $0.1 \mathrm{~m} l$ of $0.05 \mathrm{M}$ glucose-6-phosphate to both cells, the blank being devoid of NADP. Supernatant fractions from $50 \%(\mathrm{w} / \mathrm{v})$ liver homogenates in $0.15 M \mathrm{KCl}$ containing $1 \mathrm{~m} M$ EDTA, $0.02 M$ mercaptoethanol, and $0.005 \mathrm{M} \mathrm{MgCl}_{2}$
(pH 7.4) were prepared by centrifugation at $30,000 \mathrm{~g}$ for 60 minutes at $0^{\circ}$. The activity was expressed in standard units ( $\mu$ moles of NADPH formed per minute). Protein contents were determined by the method of Lowry, et $\mathrm{a}^{18)}$.

2.3 Incorporations of $\left[{ }^{3} \mathrm{H}\right]$ thymidine and $\left[\mathrm{U}-{ }^{14} \mathrm{C}\right]$ glucose into rat liver DNA

At the 4th week after feeding with $3^{\prime}$-Me$\mathrm{DAB}$, rats were injected intraperitoneally with $40 \mu \mathrm{Ci}$ of $\left[\mathrm{U}^{-14} \mathrm{C}\right]$ glucose (specific activity: $333 \mathrm{mCi} / \mathrm{mmole}$ ), and $40 \mu \mathrm{Ci}$ of $\left[{ }^{3} \mathrm{H}\right]$ thymidine (specific activity: $48 \mathrm{Ci} / \mathrm{mmole}$ ), both $\mathrm{New}$ England Nuclear Co., USA and sacrificed $2 \mathrm{hr}$ later. The livers were removed after rapid perfusion with isotonic saline, then blotted, and weighed. One gram of liver was homogenized in 5 volumes of cold $0.03 \mathrm{M}$ Tris- $\mathrm{HCl}$ buffer (pH 7.4) using a Potter-type glass homogenizer. The nucleic acid was fractionated from the homogenate by the methods of Schmidt and Thannhauser ${ }^{19)}$ and of Schneider ${ }^{20)}$. Radioactivities of ${ }^{14} \mathrm{C}$ and ${ }^{3} \mathrm{H}$ in DNA extracts were measured in toluene-triton X-100 (2:1) scintillator in an Aloka LSC-651 liquid scintillation counter with external standardization.

\section{Results}

\subsection{Radiorespirometry}

The contribution of HMP pathway to glucose metabolism at an early stage during feeding with

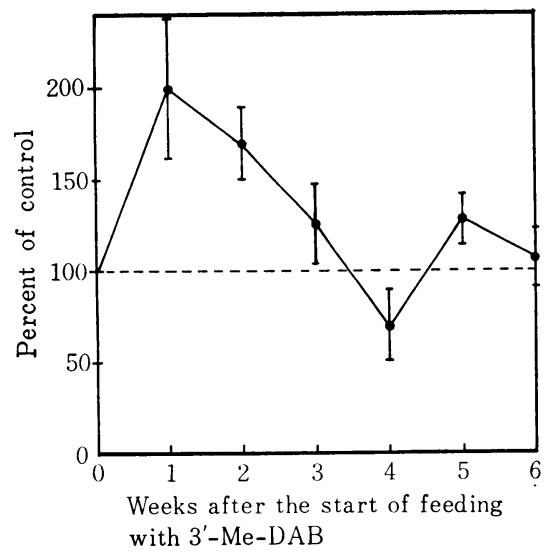

Fig. 1 Changes in peak time during feeding with $3^{\prime}-\mathrm{Me}-\mathrm{DAB}$. Results were calculated as percent of the control. The control was arbitrarily taken as $100 \%$. Vertical lines indicate the standard deviations $(n=4)$. 


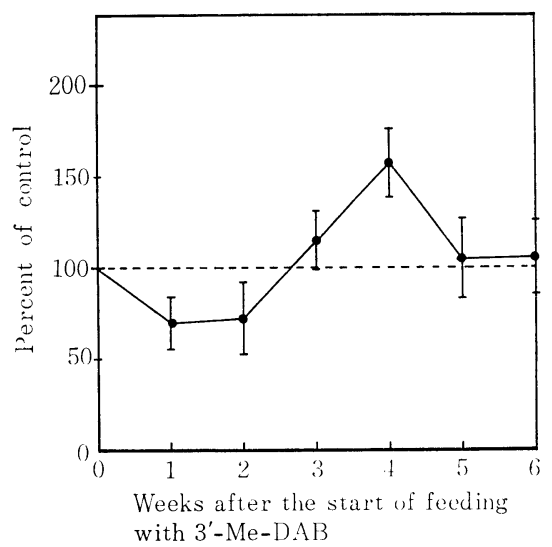

Fig. 2 Peak heights during feeding with $3^{\prime}-\mathrm{Me}^{-}$ DAB. Results were calculated as percent of the control. The control was arbitrarily taken as $100 \%$. Vertical lines indicate the standard deviations $(n=4)$.

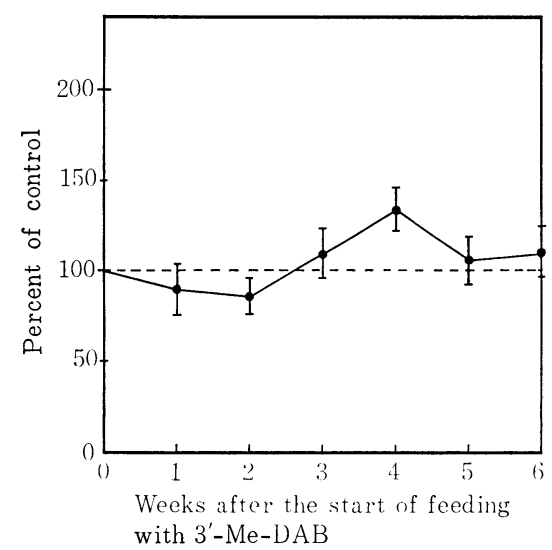

Fig. 3 Yield values during feeding with $3^{\prime}-\mathrm{Me}^{-}$ DAB. Results were calculated as percent of the control. The control was arbitrarily taken as $100 \%$. Vertical lines indicate the standard deviations $(n=4)$.

$3^{\prime}$-Me-DAB was estimated from the changes in radiorespirometry and in glycolytic and nonglycolytic enzyme activities. In order to assess the relative importance of the non-glycolytic pathway of carbohydrate metabolism, we carried out radiorespirometry using $\left[1^{-14} \mathrm{C}\right]$ glucose and $\left[6^{-14} \mathrm{C}\right]$ glucose for 6 weeks during feeding with 3'-Me-DAB. The results are shown in Figs. 1-4. As shown in Fig. 1, peak time (PT) was markedly delayed at the 1 st week, and recovered from the 2 nd to reach the control level at the 3rd week. At the 4 th week, however, PT was

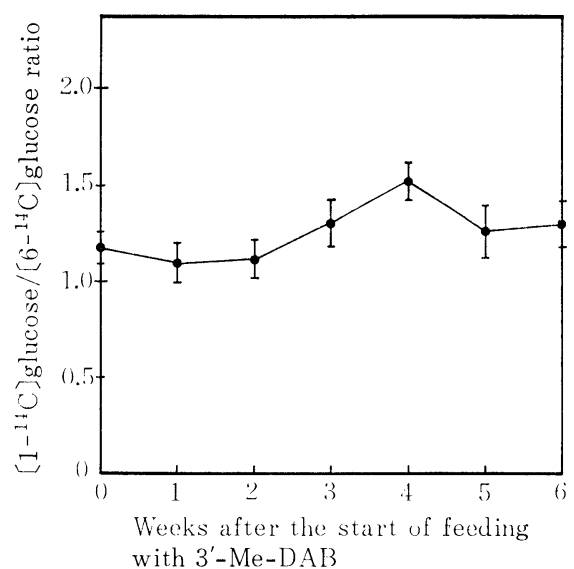

Fig. 4 Yield value ratios of ${ }^{14} \mathrm{CO}_{2}$ from $\left[1{ }^{14} \mathrm{C}\right]$ glucose to that from $\left[6^{-14} \mathrm{C}\right]$ glucose during feeding with $3^{\prime}-\mathrm{Me}-\mathrm{DAB}$.

Values represent the mean \pm standard deviation $(n=4)$.

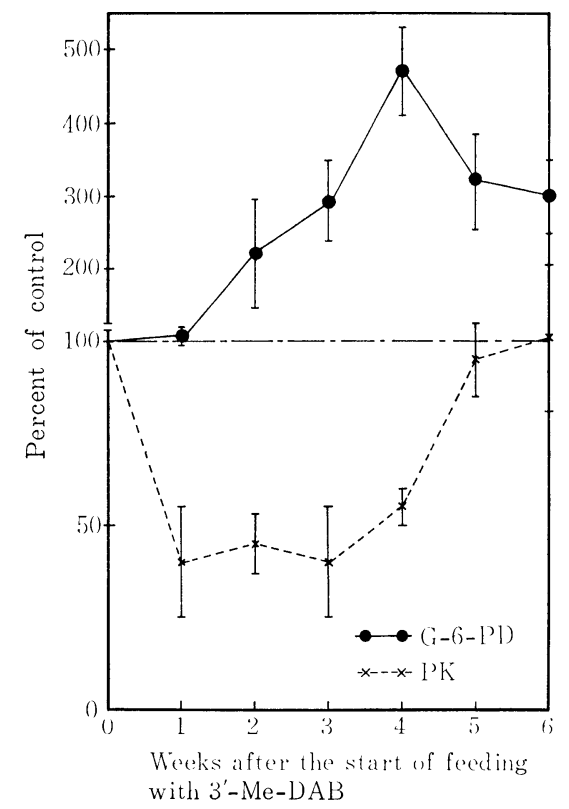

Fig. 5 Activities of $\mathrm{G}-6-\mathrm{PD}$ and $\mathrm{PK}$ during feeding with $3^{\prime}-\mathrm{Me}-\mathrm{DAB}$.

Results were calculated as percent of the control. The control was arbitrarily taken as $100 \%$.

Vertical lines indicate the standard deviations $(n=4)$.

early, but by the 5 th week and thereafter, it coincided with the control. The peak height (PH), as shown in Fig. 2, decreased to about $70 \%$ of the control level at 1 st to 2 nd week 
but started to increase at the 3rd week, reaching a maximum at 4 th week. The yield value (YV) (Fig. 3) showed almost the same pattern of changes as the peak height. On the other hand, the pattern of the yield value ratio of respiratory ${ }^{14} \mathrm{CO}_{2}$ from $\left[1^{-14} \mathrm{C}\right]$ glucose to that from $\left[6^{-14} \mathrm{C}\right]$ glucose is shown in Fig. 4. The ratio increased from 1.3 to 1.52 at the 3 rd to 4 th week during feeding with $3^{\prime}$-Me-DAB.

\subsection{Activities of G-6-PD and PK}

The changes of G-6-PD activity are shown in Fig. 5. The activity began to rise significantly from the 2nd week, reaching about 5 times the control level, and thereafter the activity remained high, with little decrease from the maximum by the 6 th week. In addition, PK, a key enzyme in the glycolytic pathway, also as shown in Fig. 5, was markedly inhibited immediately after the start of feeding with $3^{\prime}$ Me-DAB and recovered to the control level by the 5 th week.

$3 \cdot 3\left[{ }^{3} \mathrm{H}\right]$ thymidine and $\left[\mathrm{U}-{ }^{14} \mathrm{C}\right]$ glucose incorporations into rat liver DNA

The incorporations of $\left[{ }^{3} \mathrm{H}\right]$ thymidine and [U-14 C] glucose into rat liver DNA at the 4th week after the administration of $3^{\prime}$-Me-DAB are summarized in Table 1 . In the 4 th week, they increased by $180 \%$ for $\left[{ }^{3} \mathrm{H}\right]$ thymidine and $390 \%$ for $\left[\mathrm{U}-{ }^{14} \mathrm{C}\right]$ glucose respectively, over the control.

Table 1 Incorporations of $\left[{ }^{3} \mathrm{H}\right]$ thymidine and $\left[\mathrm{U}-{ }^{14} \mathrm{C}\right]$ glucose into rat liver DNA

\begin{tabular}{c|c|c}
\hline & $\begin{array}{c}{\left[{ }^{3} \mathrm{H}\right] \text { thymidine }} \\
(\mathrm{dpm} / \mathrm{mg} \text { DNA })\end{array}$ & $\begin{array}{c}{\left[\mathrm{U}-{ }^{14} \mathrm{C}\right] \text { glucose }} \\
(\mathrm{dpm} / \mathrm{mg} \text { DNA })\end{array}$ \\
\hline Control & $\begin{array}{c}18,335 \pm 3,667 \\
(100)\end{array}$ & $\begin{array}{c}5,520 \pm 1,741 \\
(100)\end{array}$ \\
\hline $3^{\prime}-\mathrm{Me}-\mathrm{DAB}$ & $\begin{array}{c}72,779 \pm 10,917 \\
(397)\end{array}$ & $\begin{array}{c}9,983 \pm 2,445 \\
(181)\end{array}$ \\
\hline
\end{tabular}

* Three rats were used for each group. They were received $40 \mu \mathrm{Ci}$ of each labelled compound at 4 th week after the start of feeding with $3^{\prime}$ $\mathrm{Me}-\mathrm{DAB}$. Each value represents the mean \pm standard deviation. Figures in parentheses are percentages relative to the control $(100 \%)$.

\section{Discussion}

In order to determine whether the nonglycolytic pathway of glucose metabolism is activated at an early stage during feeding with 3'-Me-DAB, we carried out radiorespirometry using $\left[1^{-14} \mathrm{C}\right]$ glucose and $\left[6^{-14} \mathrm{C}\right]$ glucose, and also determined the activity of G-6-PD. The use of these labelled compounds gave more clear-cut results than the previous radiorespirometric analysis using $\left[\mathrm{U}-{ }^{14} \mathrm{C}\right]$ glucose. That is to say, three parameters of the radiorespirometric pattern were activated at the 4 th week after the start of administration of 3'-Me-DAB. These changes coincided well with that of G-6PD activity. Furthermore, high proliferative activity was found at this stage in terms of the incorporation of $\left[{ }^{3} \mathrm{H}\right]$ thymidine.

In a series of reports" ${ }^{21-23)}$ entitled "Precancerous Changes in Rat Liver during the Early Stage of 3'-Methyl-4-(dimethylamino) azobenzene Carcinogenesis" ,Onoe, et al. reported that pronounced degeneration of hepatocytes occurred, and the original hepatocytes gradually disappeared, being replaced by a proliferation of cholangiolar cells (the so called oval cells)after 2 weeks of ingestion of $0.06 \% 3^{\prime}$-Me-DAB. Oval cell proliferation reached a maximum at the 4 th week after the administration of $3^{\prime}$-Me-DAB. Another interesting finding at this stage is a transient appearance of $\alpha$-fetoprotein in the sera of rats, as reported by Watabe. ${ }^{17)}$ The elevation of glucose metabolism at this stage may be due to activation of the non-glycolytic pathway together with extensive cell proliferation. While, inhibitions of glucose metabolism by the 2nd week after feeding with 3'-Me-DAB may be mainly due to inactivation of glycolytic enzymes by the toxic effects of this carcinogen. Similar results ${ }^{24 \sim 25)}$ were obtained in cases of acute liver injury due to $\mathrm{CCl}_{4}$, and in regenerating rat liver.

It seems desirable to extend the present work to an invesitigation of glucose metabolism in the newly formed hepatocytes.

\section{References}

1) Kojima, S., Shiki, Y., and Kubodera, A.: Radioisotopes, 27, (2) 78 (1979)

2) Glock, G.E., and McLean, P.: Biochem. J., 55, 400 (1953)

3) Glock, G.E., and McLean, P.: ibid., 56, 171 (1954)

4) Schmitz, H., Potter, V.R., and Hurbert, 
R.B.: Cancer Res., 14, 66 (1954)

5) Busch, H., Fujiwara, E., and Keer, L.M.: ibid., 20, 50 (1960)

6) Bottomley, R.H., Pitot, H.C., and Potter, V.P.: ibid., 23, 400 (1963)

7) Morris, H.P., and Weber, G.: ibid., 23, 987 (1963)

8) Sharma, R.M., Sharma, C., Donnelly, A.J., Morris, H.P., and Weinhouse, S.: ibid., 25, 193 (1964)

9) Shonk, C.E., Morris, H.P., and Boxer, G.E.: ibid., 25, 671 (1964)

10) Gumaa, K.A., and McLean, P.: Biochem. J., 115, 1009 (1969)

11) Hori, S.H., and Sasaki, M.: Cancer Res., 29, 880 (1969)

12) Poirier, L.A., and Pitot, H.C.: ibid., 30, 1974 (1970)

13) Watanabe, A., and Taketa, K.: J. Biochem., 73, 771 (1973)

14) Taketa, K., Tanaka, A., and Watanabe, A.: Proc. Symp. Chem. Physiol. Pathol., 11, 30 (1971)
15) Glock, G.E., and McLean, P.: Biochem. $J ., 61,390$ (1955)

16) Field, J.B., Pastan, I., Johnson, P., and Herring, B.: J. Biol. Chem., 235, 1863 (1960)

17) Watabe, H.: Cancer Res., 31, 1192 (1971)

18) Lowry, O.H., Rosenbrough, N.J., Farr, A.L., and Randall, R.J.: J. Biol. Chem., 193, 256 (1951)

19) Schmidt, G., and Thannhauser, S.J.: ibid., 161, 83 (1945)

20) Schneider, T.W., Bushnell, D.E., and Potter, V.R.: Cancer Res., 30, 1867 (1970)

21) Iwasaki, T., Dempo, K., Kaneko, A., and Onoe, T.: Gann, 63, 21 (1972)

22) Kaneko, A., Dempo, K., Iwasaki, T., and Onoe, T.: ibid., 63, 31 (1972)

23) Kaneko, A., Dempo. K., and Onoe, T.: ibid., 63, 41 (1972)

24) Kojima, S., and Kubodera, A.: Jap. J. Nucl. Med., 16, (2) 141 (1979)

25) Kojima, S., and Kubodera, A.: Radioisotopes, in preparation

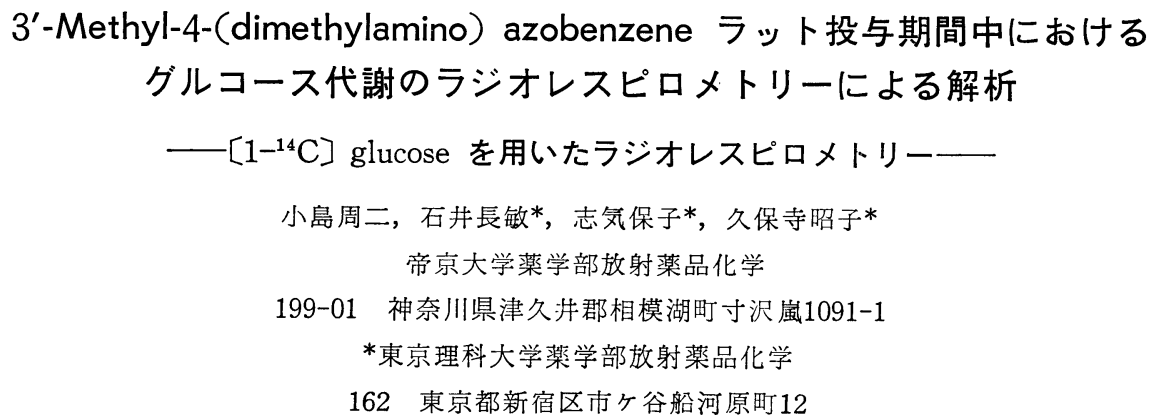

$3^{\prime}$-Methyl-4-(dimethylamino) azobenzene（3'-Me-DAB）投与初期に扮いて五炭糖リン酸回路に よる糖代謝の活性化をわれわれはさきの報告にて予測した。今回, 前がん状態肝に括ける，この非 解糖系回路による糖代謝の活性化を，1拉よび 6 位標識グルコースを用いたラジオレスピロメトリ 一にて明らかにした。 $\left[1{ }^{14} \mathrm{C}\right]$ glucose によるラジオレスピロメトリーに颃いて, peak time は $3^{\prime}$ $\mathrm{Me}-\mathrm{DAB}$ 投与後 2 週目まで著しく遅れたが， 3 週目でほほ正常值を示し，逆に 4 週目で早まり， $5 ， 6$ 週目ではふたたび正常の速さとなった。 peak height, yield value はいずれも peak timeの 変動とともに变化し, 早まるさいには增加し, 遅れるさいには低下した。一方呼気排泄 ${ }^{14} \mathrm{CO}_{2}$ の C1/C-6 比は 4 週目で1.52まで上昇した。また G-6-PD 活性も 4 週目で最高值を示した。 